\title{
ELIMINASI RISIKO OPERASIONAL BMT SRI SEJAHTERA SURABAYA ${ }^{1}$
}

\author{
Yanuar Dharma Putra \\ Departemen Ekonomi Syariah- Fakultas Ekonomi dan Bisnis-Universitas Airlangga \\ Email: yanuar-d-p-11@feb.unair.ac.id \\ Imron Mawardi \\ Departemen Ekonomi Syariah- Fakultas Ekonomi dan Bisnis-Universitas Airlangga \\ Email: imron.mawardi@feb.unair.ac.id
}

\begin{abstract}
:
The results of this research are risk mitigation measures in the continuity of internal processes, human resources, technology and information. Risk mitigation on the internal processes is done by performing supervision based on employees job description, and implementation of sharia financing agreements with customers. Risk mitigation on human resources is done by providing moral guidance to employees. Risk mitigation in information technology is carried out by performing regular maintenance of computer software and hardware, as well as other devices that support Baitul Maal wa tamwil Sri Sejahtera business activities.
\end{abstract}

\section{PENDAHULUAN}

\section{Latar Belakang}

Chapra (2000:7) menjelaskan bahwa ekonomi Islam dibangun berdasarkan konsep-konsep tentang kebahagiaan manusia (falah) dan kehidupan yang baik (hayatan thayyiba) yang sangat mengedepankan aspek persaudaraan (ukhuwwah), keadilan sosioekonomi dan pemenuhan kebutuhan-kebutuhan spiritual umat manusia.

Ekonomi Islam idealnya mampu memberdayakan perekonomian masyarakat agar manusia terbatas dari kemiskinan dan tercipta kekuatan ekonomi. Salah satu langkah adalah dengan adanya lembaga keuangan syariah. Lembaga inilah yang kemudian mengelola dana berlebih dari sekelompok orang yang mengalirkan kepada sekelompok orang yang membutuhkan dana untuk dikelola dalam kegiatan yang produktif. Sehingga tidak ada dana yang menganggur dan tidak ada keahlian yang menganggur pula. Keduanya dipertemukan oleh lembaga keuangan syariah dan membuat pola roda perekonomian berputar.

Lembaga kevangan Islam bisa berbentuk bank maupun non-bank, seperti asuransi syariah, gadai syariah, pasar modal syariah, maupun koperasi syariah. Baitul maal wa tamwil (BMT) merupakan lembaga keuangan non-bank yang berorientasi sosial keagamaan yang berbadan hukum Koperasi Simpan Pinjam Pembiayaan Syariah (KSPPS). Dalam menjalankan kegiatan operasionalnya BMT mendasar pada UU No. 25 Tahun 1992 tentang perkoperasian pasal 3, yaitu koperasi bertujuan memajukan

\footnotetext{
${ }^{1}$ Jurnal ini merupakan bagian dari skripsi Yanuar Dharma Putra, NIM: 041114176 , yang telah diuji pada tanggal 15 Januari 2018.
} 
kesejahteraan pada khususnya dan masyarakat pada umumnya, dan ikut serta membangun tahanan perekonomian nasional dalam rangka mewujudkan masyarakat adil dan makmur yang berlandaskan Pancasila dan Undang-Undang Dasar 1945.

Dalam menjalankan kegiatan usahanya, risiko merupakan ssesuatu yang wajar pada sebuah lembaga keuangan. Karim (2006:260) menjelaskan risiko-risiko yang melekat pada aktivitas fungsional lemabaga keuangan syariah dapat diklasifikan ke dalam tiga jenis risiko, yaitu risiko pembiayaan, risiko pasar, dan risiko operasional.

Salah satu risiko yang dihadapi lembaga keuangan dalam kegiatan usahanya adalah risiko operasional. Risiko operasional dapat menimbulkan kerugian keuangan secara langsung maupun tidak langsung dan kerugian potensial atas hilangnya kesempatan memperoleh keuntungan. Khan dan Ahmad (2008:13) menjelaskan risiko operasional adalah konsep yang tidak terdefinisikan dengan jelas, risiko ini muncul akibat kesalahan atau kecelakaan yang bersifat manusiawi ataupun teknis. Risiko operasional merupakan tipe risiko yang paling tua, tetapi paling sedikit dipahami dibandingkan dengan risiko lainnya (Hanafi, 2009:196)

Risiko dapat dikelola apabila telah melakukan identifikasi atas aktivitas yang dilakukan. Setelah dipetakan bagaimana sebenarnya risiko bisa terjadi, barulah rumusan mengenai mitigasi risiko dapat dibuat. Mitigasi risiko dilakukan sebagai salah satu usaha untuk meminimalisir dampak negative yang nantinya harus diterima akibat terjadinya kenyataan yang tidak sesuai dengan ekspektasi.

Mitigasi risiko menjadi hal yang penting karena akan mempengaruhi pencapain tujuan BMT, yaitu pencapaian maslahah. Maslahah dapat dijabarkan dengan tercapainya kesejahteraan umat (falah). Jika risiko tidak dapat dimitigasi dengan baik, maka kesejahteraan umat akan menjadi terganggu. Risiko operasional yang muncul jika mitigasi risiko tidak berjalan dengan baik, seperti risiko di dalam menjalankan proses internal (internal fraud), risiko sumber daya manusia (human error), dan risiko kegagalan sistem akan berpotensi muncul. Dampaknya akan mengganggu kegiatan usaha yang berpengaruh pada keuntungan BMT.

\section{Rumusan Masalah}

Berdasarkan latar belakang yang telah diuraikan di atas, maka rumusan masalah yang diambil adalah Bagaimana Mitigasi Risiko Operasional pada Baitul Maal wa Tamwil Sri Sejahtera.

\section{Tujuan Penelitian}

Penelitian ini mempunyai tujuan untuk mengetahui bagaimana Mitigasi Risiko Operasional pada Baitul Maal wa Tamwil Sri Sejahtera.

\section{TINJAUAN PUSTAKA}

Baitul Maal Wa Tamwil 
Baitul Maal wa Tamwil (BMT) terdiri dari dua rangkaian kata, yakni baitul maal dan baitul tamwil. IImi (2002:65) berpendapat bahwa baitul maal (rumah harta) merupakan lembaga keuangan yang berorientasi sosial keagamaan yang kegiatan utamanya adalah menampung dan menyalurkan zakat, infaq, dan shadaqah sesuai dengan peraturan yang ada di Al-Qur'an dan Sunnah Rasul-Nya, sedangkan baitul tamwil (rumah pembiayaan) merupakan lembaga keuangan yang kegiatan utamanya meghimpun dana masyarakat dalam bentuk (simpanan) maupun deposito dan menyalurkannya kembali kepada masyarakat dalam bentuk pembiayaan berdasarkan prinsip syariah melalui mekanisme yang lazim di dunia perbankan.

\section{Tujuan Dan Peran Bmt}

Mughni (2005) menjelaskan didalam menjalankan operasinya, BMT memiliki fungsi dan peranan antara lain:

1. Mengidentifikasi, memobilisasi, mengorganisir, mendorong, dan mengembangkan potensi ekono mi dan daerah kerjanya.

2. Menggalang dan memobilisir potensi masyarakat dalam rangka meningkatkan kesejahteraan.

3. Menjadi perantara keuangan (financial intermediary) antara kaya dan miskin untuk dana-dana sosial dan pengembangan usaha produktif.

\section{Prinsip Operasional BMT}

Dalam menjalankan kegiatan operasionalnya, BMT yang berbadan hukum KSPPS beroperasi layaknya bank dan menggunakan prinsip: 1) Prinsip Bagi Hasil, 2) Sistem Jual Beli, 3) Sistem NonProfit, 4) Akad Bersyariat, dan 5) Produk Pembiayaan. Namun, tidak dapat melakukan transaksi transfer, kliring, dan giro (Sudarsono, 2008:108)

Suhendi (2009) berpendapat bahwa untuk mencapai keberhasilan dalam melaksanakan kegiatan pembiayaan kepada masyarakat, BMT dapat menerapkan prinsip sebagai berikut:

1. Prinsip kehati-hatian (prudential principle) dalam melaksanakan kegiatannya, terutama dalam pemberian pembiayaan kepada masyarakat.

2. Prinsip mengenal nasabah (know your customer principle), hal ini lebih menekankan aspek karakter nasabah.

3. Secara internal perlu menerapkan prinsip-prinsip good corporate governance (GCG), yang meliputi transparency, accountability, independence, dan fairness.

\section{Produk-Produk BMT}

1. Produk Penghimpunan Dana

Muhammad (2004:6) menjelaskan tabungan wadiah adalah simpanan yang penarikan dananya dapat dilakukan sewaktu-waktu. Penarikan dana tabungan dapat dilakukan menurut syarat dan ketentuan yang berlaku. Simpanan BMT yang menggunakan akad wadiah 
terdiri dari dua macam, yaitu Wadiah Yad Al-Amanah dan Wadiah Yad AdhDhamanah.

$$
\text { Mudharabah adalah simpanan }
$$

yang penyetoran dan penarikannya dapat dilakukan sesuai dengan perjanjian yang telah disepakati sebelumnya (Muhammad, 2004:6). Dana yang diperoleh dari anggota dipergunakan oleh BMT untuk disalurkan ke pembiayaan yang sesuai syariah. Pendapatan yang dibagikan BMT ke anggota berupa bagi hasil. Deposito BMT yang menggunakan akad mudharabah terdiri dari dua macam, yaitu Mudharabah Muqqayadah dan Mudharabah Mutlaqah.

\section{Produk Penyaluran Dana}

Dana yang telah diperoleh BMT disalurkan ke pihak yang membutuhkan dalam bentuk pembiayaan. Pembiayaan digunakan untuk mengembangkan dan meningkatkan pendapatan anggota dan BMT, serta untuk memanfaatkan dana agar tidak menganggur. Muhammad (2002:90) menjelaskan produk pembiayaan dana di BMT dapat dikembangkan dengan empat model, yaitu:

a. Prinsip jual beli yang dikembangkan menjadi bentuk pembiayaan murabahah, salam, dan istishna.

b. Prinsip sewa yang dikembangkan menjadi bentuk pembiayaan ijarah dan ijarah muttabiyah bittamlik.

c. Prinsip bagi hasil yang dikembangkan menjadi bentuk pembiayaan musyarakahdan mudharabah. d. Qardhul hasan, pembiayaan sesuai prinsip syariah dengan tidak adanya biaya dalam mengembalikan dana tersebut.

Risiko

Menurut Peraturan Bank Indonesia No. 11/25/PBI/2009 tentang Penerapan Manajemen Risiko Bagi Bank Umum. Risiko adalah potensi kerugian akibat terjadinya suatu peristiwa (events) tertentu. Karim (2006:216) berpendapat, risiko dalam konteks perbankan merupakan kejadian potensial, baik yang dapat diperkirakan (anticipated) maupun yang tidak dapat diperkirakan (unanticipated) yang berdampak negative terhadap pendapatan dan permodalan lembaga keuangan.

Peraturan Bank Indonesia No. 11/25/PBI/2009 juga telah mengklasifikasikan berbagai macam risiko menurut kejadiannya, sebagai berikut:

a. Risiko Kredit

b. Risiko Pasar

c. Risiko Likuiditas

d. Risiko Operasional

e. Risiko Kepatuhan

f. Risiko Hukum

g. Risiko Reputasi

\section{Risiko Dalam Perspektif Islam}

Risiko dalam bisnis tidak dapat ditiadakan, namun hanya bisa dikelola saja sehingga dapat meminimalisir dampak dari risiko tersebut. Islam memandang bahwa risiko dalam kegiatan usaha merupakan sebuah sunnatullah dalam kegiatan usaha. Hal 
tersebut sesuai dengan firman Allah pada surat Al-Luqman ayat 34 sebagai berikut. "Sesungguhnya Allah, hanya pada sisiNya sajalah pengetahuan tentang hari Kiamat; dan Dia-lah yang menurunkan hujan, dan mengetahui apa yang ada dalam rahim. dan tiada seorangpun yang dapat mengetahui (dengan pasti) apa yang akan diusahakannya besok. dan tiada seorangpun yang dapat mengetahui di bumi mana Dia akan mati. Sesungguhnya Allah Maha mengetahui lagi Maha Mengenal."

Sebuah usaha dalam menjalankannya tidak terlepas dari risiko. Manusia hanya berusaha dan berdoa dan hasi usahanya diserahkan kepada Allah. Sebuah ketentuan penting dalam syariah yang terkait dengan sistem kevangan Islam adala al ghorn bil ghom dan al khiraj bil daman. Arti fundamental bisnis Islam adalah tidak ada hasil yang diperbolehkan tanpa adanya sebuah risiko yang ditanggung dan didalam pendapatan yang diperoleh terdapat kewajiban yang melekat padanya (Khan dan Ahmad, 2008:23).

\section{Manajemen Risiko}

Definisi mengenai manajemen risiko cukup banyak, diantaranya adalah Comitte of Sponsoring Organization of the Tradeaway Commision (COSO), mendefinisikan manajemen risiko perusahaan (Enterprise Risk Management) sebagai sebuah proses yang dipengaruhi oleh dewan perusahaan, manajemen dan personil lain entitas tersebut, diterapkan dalam penetepan strategi risiko agar tetap ada dalam jangkauan risikonya, sehingga dapat memberikan jaminan yang wajar mengenai pencapaian tujuan entitas (Alijoyo, 2006:89).

Baitul maal wa tamwil memerlukan proses manajemen risiko agar dapat mencapai tujuannya, yaitu kesejahteraan dunia dan akhirat (falah). BMT harus memiliki manajemen risiko yang berkualitas agar pembiayaan yang disalurkan tidak mengalami gagal bayar tanpa meninggalkan sisi kesyariahannya (sharia compliance) dan dari sisi hukum positif atau undang-undang yang berlaku. Redja (2008:43) menjelaskan langkah-langkah dalam proses manajemen risiko. Beberapa langkah tersebut adalah sebagai berikut:

1. Mengidentifikasi risiko

2. Menganalisis nilai risiko tersebut

3. Memilih teknik yang sesuai untuk menangani risiko yang ada

4. Mengimplementasikan dan mengawasi manajemen risiko

Identifikasi risiko merupakan langkah awal dalam manajemen risiko. Identifikasi risiko yang dilakukan oleh lembaga keuangan syariah tidak hanya mencakup risiko yang ada pada lembaga keuangan konvensional pada umumnya, melainkan juga meliputi risiko khusus yang terdapat pada lembaga keuangan syariah. Salah satunya adalah risiko kepatuhan lembaga keuangan syariah 
terhadap prinsip-prinsip syariah dalam setiap aktivitasnya.

Analisis risiko yang telah diidentifikasi perlu dilakukan dengan cermat untuk mengetahui risiko mana yang paling berbahaya (risiko tinggi) dan risiko mana yang terendah dan seterusnya. Selanjutnya pemilihan teknik perlakuan risiko harus dilaksanakan dengan tepat, Redja (2008;45) menjelaskan membagi teknik perlakuan risiko dibagi menjadi dua, ykni risk control dan risk financing.

\section{Mitigasi Risiko}

Mitigasi adalah eliminasi atau mengurangi frekuensi, besarnya, kerasnya atau eksposur dari sebuah risiko, atau meminimalisasi dampak potensial dari ancaman atau peringatan (Darmawi, 2008:43). Tujuan mitigasi risiko adalah mengeksplorasi strategi respon atas sesuatu yang berisiko, diidentifikasi dalam analisis risiko kualitatif dan kuantitatif (Khan, 2008:52).

International Organization for

Standardization (ISO) (31000:2009), menjelaskan istilah mitigasi risiko disebut dengan risk treatment. Dalam menghadapi risiko terdapat empat penanganan yang dapat dilakukan oleh organisasi, antara lain: 1) menghidari risiko (risk avoidance), 2) mitigasi risiko (risk reduction), 3) transfer risiko kepada pihak ketiga (risk sharing), dan 4) menerima risiko (risk acceptance).

Mitigasi idealnya dilakukan dengan analisis terlebih dahulu yang mendasarkan pada beberapa pertimbangan. Hal ini dilakukan agar mitigasi yang dipilih tepat menghadapi risiko, sehingga dapat meminimalisasi kerugian yang timbul

Mitigasi harus melingkupi berbagai kontrol yang saling tumpang tindih. Beberapa diantaranya proses yang ditujukan untuk mengurangi kemungkinan suatu informasi kegagalan, dan beberapa bagian lain bekerja untuk mengurangi jumlah kerugian yang disebabkan oleh kegagalan itu. Fungsi kontrol memastikn bahwa apapun bentuknya di mana ancaman terwujud, maka ada suatu kesempatan atau lebih kontrol aka nada untuk memitigasi risiko (Darmawi, 2008:45).

\section{Risiko Operasional}

Pengelolaan risiko operasional merupakan bagian integral dari manajemen risiko perusahaan. Risiko-risiko yang terkait dengan aktivitas bisnis harus diidentifikasi, diukur, diniliai, dimitigasi, dan dikendalikan oleh pengurus lembaga keuangan.

Risiko operasional menurut Djohanputro (2006), yaitu potensi penyimpangan dari hasil yang diharapkan karena tidak berfungsinya suatu sistem, sumber daya manusia, teknologi, atau faktor lainnya. Risiko operasional mempunyai dimensi yang luas dan komplek dengan sumber risiko yang merupakan gabungan dari berbagai sumber yang ada dalam organisasi, proses dan kebijakan, sistem dan teknologi, orang, dan faktor-faktor lainnya. 
Frame J. Davidson (2003) membagi sumber risiko operasional pada umumnya dalam beberapa hal, yakni:

1. Lemahnya penerapan prosedur

2. Kurangnya pelatihan kerja

3. Tidak kompeten

4. Perhatian yang lemah

5. Kurangnya perawatan peralatan dan software

Berikut struktur risiko operasional berdasarkan Basel Capital Accord yang dibagi dalam dua kategori yaitu internal failure dan external failure.

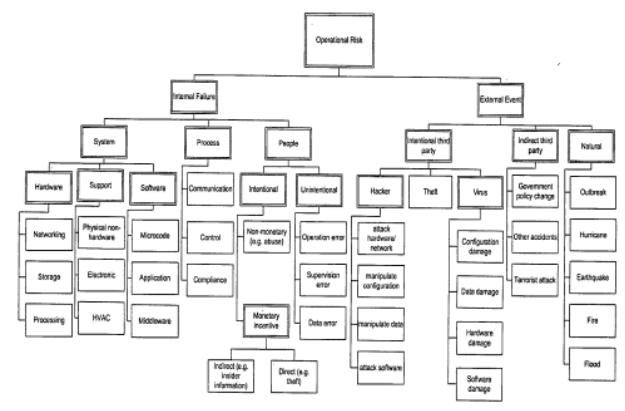

Sumber: Supatgiat, Kenyon dan Heusler. 2006

\section{Gambar 1. Struktur Risiko Operasional}

\section{Mekanisme Terjadinya Risiko Operasional}

Alexander (2003) mengemukakan

bahwa suatu risiko operasional timbul karena adanya sebab (cause), yaitu suatu hal utama yang meningkatkan kemungkinan terjadinya suatu kejadian (events). Cause berpotensi menghasilkan peristiwa-peristiwa yang tidak diinginkan. Dari events risiko operasional yang ada, akan memberikan akibat atau dampak (impact) terhadap perusahaan, akibat umum yang ditimbulkan dapat berupa kerugian material secara finansial atau kerusakan aset fisik atau berupa kerugian kualitatif. Risiko operasional dapat dianalisis pada setiap tingkat.

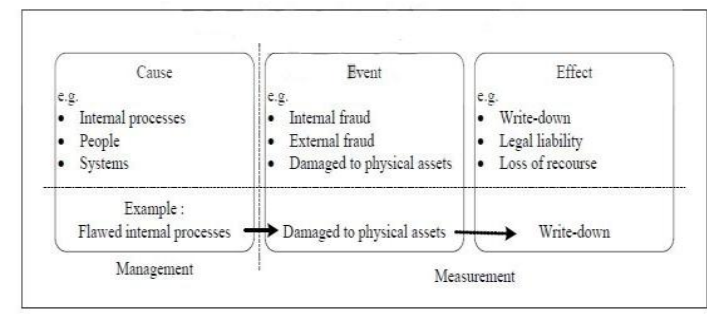

Gambar 2.

Analisis Risiko Operasional

Sumber: Dowd Victor, Alexander. 2003. Operational Risk: Regulation, Analysis and Management. London: Prentice Hall

\section{Risiko Pada Lemabaga Keuangan Syariah}

Lembaga keuangan syariah menghadapi berbagai risiko dalam operasionalnya. Mirakhor dan lqbal (2008:27) mengelompokkan risiko menjadi empat kategori yang luas, yakni risiko finansial, risiko bisnis, risiko keuangan, dan risiko tata kelola (governance). Lembaga keuangan syariah terbuka bagi risiko tingkat pengembalian (rate of return risk) dan risiko kemampuan membayar (solvency risk) (Mirakhor dan labal, 2008:295). Risiko keuangan mencakup risiko yang bersumber dari manajemen sumber daya finansial, institusi finansial dalam term manajemen kas, manajemen ekuitas, manajemen likuiditas jangka pendek, dan ALMA serta hedging. Risiko tata kelola mengacu pada risiko yang muncul dari pengelolaan sebuah institusi, kelalaian dalam menjalankan bisnis. Mirakhor dan labal (2008:304) menyebutkan beberapa risiko yang terkait tata kelola diantaranya risiko operasional, 
risiko fidusiaro, risiko transparansi, risiko syariah dan risiko reputasi.

\section{METODE PENELITIAN}

\section{Pendekatan Penelitian}

Penelitian ini menggunakan pendekatan kualiatif. Yin (2002:2) menjelaskan pendekatan kualitatif adalah pendekatan dengan menggunakan data yang berupa kalimat tertulis atau lisan, peristiwa-peristiwa, pengetahuan atau proyek studi yang bersifat deskriptif.

Penelitian kualitatif ini menggunakan pendekatan studi kasus. Yin (2009:1) menjelaskan bahwa studi kasus adalah strategi yang paling cocok bila pertanyaan suatu penelitian berhubungan dengan how atau why. Strategi ini sangat berguna apabila peneliti hanya punya sedikit peluang untuk mengonrtol peristiwa-peristiwa yang akan diteliti.

\section{Ruang Lingkup Penelitian}

Ruang lingkup penelitian terbatas pada pelaksanaan mitigasi risiko operasional yang meliputi beberapa aspek, yaitu, kegagalan dalam menjalankan proses internal, kesalahan manusia, kegagalan teknologi dan informasi, dan faktor-faktor eksternal yang mempengaruhi operasional BMT.

\section{Jenis Dan Sumber Data}

Data hasil penelitian diperoleh dari data primer dan data sekunder. Data primer adalah data yang diperoleh langsung dari hasil wawancara dengan informan yang dianggap kompeten dalam memberikan informasi yang relevan dan sebenarnya di lapangan. Dalam menetapkan informan menggunakan teknik snowball sampling.

Data sekunder diperoleh dari jurnal, artikel, dan literature yang dapat menjadi referensi bagi peneliti tentang kegiatan operasional lembaga keuangan syariah dan risikonya.

\section{Unit Analisis}

Dalam pengambilan informan peneliti memilih orang atau individu yang dianggap paling tahu tentang apa yang diharapkan mengenai topik yang diteliti, atau sebagai penguasa sehingga akan memudahkan peneliti menjelajahi objek yang diteliti. Dalam penelitian ini unit analisi adalah Pelaksanaan Mitigasi Risiko Operasional di Baitul Maal wa Tamwil Sri Sejahtera Surabaya.

\section{Teknik Pengumpulan Data}

Penelitian kualitatif dengan strategi studi kasus bisa didasarkan atas enam sumber bukti yang dapat dijadikan fokus bagi pengumpulan data, adalah: dokumen rekaman asip, wawancara, observasi langsung, observasi pemeran serat perangkat fisik (Yin, 2013:103). Dalam penelitian ini peneliti menggunakan wawancara dan dokumentasi untuk mengumpulkan data.

\section{Teknik Keabsahan Data}

Dalam teknik pengumpulan data, triangulasi diartikan sebagai teknik pengumpulan data yang bersifat menggabungkan dari berbagai teknik pengumpulan data dan sumber yang telah ada (Sugiyono, 2015:330). Dalam 
penelitian ini, peneliti menggunakan teknik triangulasi sumber. Triangulasi sumber digunakan untuk menguji kredibilitas data dengan cara mengecek data yang telah diperoleh melalui beberapa sumber (Sugiyono, 2015:372).

\section{Teknik Analisis Data}

Dalam penelitian ini setelah mendapatkan data yang diperoleh dari hasil wawancara dan dokumentasi, selanjutnya peneliti akan melakukan analisis data. Sebagaimana dijelaskan Miles dan Huberman dalam Sugiyono (2015:337), terdapat tiga aktivitas dalam analisis data, yaitu: Reduksi Data, Penyajian Data, dan Penarikan Kesimpulan.

\section{HASIL DAN PEMBAHASAN}

\section{Gambaran Umum Objek Penelitian}

Berdirinya Baitul Maal wa Tamwil (BMT) Sri Sejahtera diawali dari musyawara beberapa orang. Musyawarah tersebut menghasilkan pemikiran-pemikiran mengenai dibentuknya sebuah koperasi syariah serta ditetapkan pula penguruspengurusnya, antara lain: Ketua, Sekretaris, dan Bendahara. Pada bulan Oktober 2012 BMT Sri Sejahtera mengontrak sebuah tempat di Jl. Simo Kwagean No. 82 sebagai tempat musyawarah dan sebagai kantor awal BMT Sri Sejahtera.

Bulan November 2012 merupakan awal berdirinya BMT Sri Sejahtera yang beralamatkan di Jl. Simo Kwagean No. 82 Surabaya dan telah ditentukan pula pegawai-pegawainya. Berjalan tiga bulan, BMT Sri Sejahtera mulai merasa perlu untuk menambah jumlah karyawan yang kemudian dilakukan perekrutan beberapa karyawan. Satu tahun berjalan BMT Sri Sejahtera mendirikan tempat Rapat Anggota Tahunan (RAT) yang pertama bersamaan dengan itu BMT berpindah tempat pula, tepatnya di Jl. Simo Kalangan No. 192 K Surabaya.

BMT Sri Sejahtera terdaftar sebagai lembaga keuangan yang berbadan hukum Koperasi dengan Nomor P2T/01/09.01/01/1/2013 yang masih berbentuk konvensional, tetapi dalam pelaksanaan kegiatan usahanya BMT Sri Sejahtera tetap berlandaskan pada prinsip syariah.

BMT Sri Sejahtera yang awalnya Koperasi Jasa Keuangan Syariah (KJKS), mulai berganti nama menjadi Koperasi Simpan Pinjam Pembiayaan Syariah (KSPPS) pada tanggal 29 Januari 2016. Dengan bergantinya nama berganti pula pola pengawasannya. KJKS secara badan hukum dibawah naungan dan pengawasan dari Otoritas Jasa Keuangan (OJK), sedangkan pihak BMT Sri Sejahtera lebih memilih untuk berada di bawah pengawasan Kementrian Koperasi, sehingga membuat pihak BMT Sri Sejahtera mengajukan proses perubahan nama dari KJKS menjadi KSPPS, karena KSPPS berada dibawah pengawasan Kementrian Koperasi. Sedangkan secara operasional, KJKS dibawah naungan OJK dapat melayani transaksi oleh non- 
anggota, sedangkan KSPPS hanya melayani anggota.

\section{Struktur Organisasi BMT Sri Sejahtera}

BMT Sri Sejahtera berbadan hukum KSPPS, sehingga kekuasaan tertinggi berada di Rapat Anggota Tahunan (RAT). BMT Sri Sejahtera mempunyai Dewan Pengawas Syaria yang brfungsi sebagai pengawas sebagai lembaga keuangan syariah yang wajib menerapkan prinsip syariah dalam setiap operasionalnya dan sebagai rujukan pengelola dalam membuat produk baru. Berikut ini adalah jajaran pengurus BMT Sri Sejahtera berdasarkan Rapat Anggota Tahunan.

1. Dewan Syariah

Anggota : Ali Hamdan, MEI

Anggota : Kuswanto, ST

2. Pengawas Koperasi

Ketua : Dra Sri Suliyani

Anggota : Arief Johan, SE

Anggota : Nisrina Dwi Hur Ramiah

3. Pengurus Koperasi

Ketua : Drs. Mujani

Sekretaris : H. Samiran

Bendahara : Titik Endah Wijayanti, A.Md

4. Pengelola Koperasi

Manajer : Kuswanto, ST

Kep. Bag. Keuangan: Ria Puspita

Staff Keuangan : Tika Kumala (teller) dan Liska Duwi (teller)

Kep. Bag. Administrasi : Tri Agustina

Staff Administrasi : Zunaidi Arromli

Bag. Marketing : Aldi Prayana

Bag. Staff : Atik Budi Handayani, Puji Astutik dan Ika Ayu Suciati

\section{Produk Di BMT Sri Sejahtera}

BMT Sri Sejahtera dalam kegiatan usahanya memiliki akad yang dibagi menjadi dua, yaitu:

1. Penghimpunan Dana

a. Mudharabah

b. Wadiah

2. Penyaluran Dana

a. Mudharabah

b. Musyarakah

C. Murabahah

d. Salam

e. Istishna

f. ljarah

g. Qardh

\section{Risiko Operasional Pada BMT Sri Sejahtera}

Baitul Maal wa Tamwil Sri Sejahtera menganalisis risiko yang meliputi kegiatan atau proses internal, sumber daya manusia (pegawai atau karyawan), dan teknologi informasi. Berikut risiko yang teridentifikasi, yaitu:

1. Risiko kesalahan kerja (pelayanan, dokumentasi, dan pemasaran produk) oleh pegawai BMT Sri Sejahtera terhadap calon anggota atau anggota dalam mengajukan pembiayaan.

2. Risiko lemahnya pengawasan terhadap implementasi akad yang hendak diajukan oleh calon anggota atau anggota, serta pengawasan kinerja terhadap pegawai BMT Sri Sejahtera.

3. Risiko pegawai melakukan kecurangan (fraud) atau ketidakjujuran (moral hazard) dalam menjalankan job description masing-masing. 
4. Risiko kerusakan atau kehilangan datadata seperti laporang kevangan, laporan laba rugi, dan data anggota akibat kerusakan komputer dan keselahan penggunaan program.

\section{Mitigasi Risiko Operasional Di BMT Sri Sejahtera Pada Keberlangsungan Proses Internal}

Mitigasi risiko operasional pada proses internal meliputi dua tahap, yaitu melakukan pengawasan terhadap kinerja pegawai sesuai dengan job description, kedua melakukan pengawasan terhadap implementasi akad-akad pembiayaan sesuai dengan ketentuan syariah (sharia compliance). Job description pada BMT Sri Sejahtera dibagi menjadi lima, yaitu:

1. Manajer

2. Teller

3. Customer service

4. Survey dan collecting

5. Administrasi

Supervisi dilakukan oleh manajaer BMT Sri Sejahtera selaku orang yang mempunyai wewenang melakukan pengawasan. Pengawasan pada bagian customer service dilakukan berdasarkan pelayanan terhadap calon anggota atau anggota, keramahan pegawai serta penjelasan mengenai akad-akad pembiayaan menjadi tolak ukur manajer dalam menentukan kinerja pegawai.

\section{Pengawasan kedua dilakukan}

pada bagian administrasi. Manajer melakukan pengecekan terhadap laporan yang terkait dengan proposal pengajuan pembiayaan dengan form pengajuan pembiayaan yang sudah terkumpul. Apakah laporan sudah coock dengan berkas yang terkumpul atau tidak. Serta berkas-berkas terkait dengan persyaratan yang diperlukan untuk mengajukan pembiayaan, melakukan simpanan dan penarikan

Pengawasan ketiga dilakukan pada bagian teller yang berhubungan dengan keuangan. Manajer melakukan audit internal terhadap laporan keuangan day to day. Anggaran tersebut dicocokan dengan laporan keuangan yang dibuat oleh teller dengan laporan yang ada di neraca keuangan. Manajer juga melakukan pengawasan langsung terhadap kinerja teller ketika memberikan vang ketika melakukan pengeluaran dan penyimpanan uang.

Pengawasan collecting dan survey dilakukan dengan melakukan kontrol terhadap pelaksanaan survey apakah sudah sesuai domisili, tempat tinggal dan pekerjaan dengan keterangan yang diberikan oleh calon anggota atau anggota. Kinerja pegawai collecting juga diawasi ketika pegawai mendapatkan titipan angsuran dari anggota, manajer melakukan kroscek by phone dengan anggota yang menitipkan angsurannya kepada pegawai.

Pengawasan terhadap implementasi akad juga dilakukan oleh manajer BMT Sri Sejahtera karena manajer juga merangkap sebagai Dewan Pengawas Syariah (DPS). DPS mengontrol pemahaman pegawai terhadap akad- 
akad pembiayaan yang diajukan oleh anggota.

\section{Mitigasi Risiko Di BMT Sri Sejahtera Terhadap Sumber Daya Manusia}

BMT Sri Sejahtera tidak hanya berfokus pada pengawasan kinerja pegawai. Pengawasan moral terhadap pegawai juga dilakukan, karena BMT Sri Sejahtera merupakan bagian dari lembaga dakwah yang didalam kegiatan usahanya wajib memberikan bimbingan moral terhadap pegawainya.

$$
\text { Pengawasan moral dilakukan }
$$
manajer dengan mengawasi aktivitas pegawai selama jam kerja. Bimbingan spiritual juga selalu diberikan setiap pagi oleh manajer sebagai langkah awal dalam menjalankan kegiatan usaha supaya mendapatkan ridha Allah, BMT juga mengadakan bimbingan rutin satu kali dalam sepekan berupa pengajian dan bimbingan yang terkait dengan pekerjaan.

\section{Mitigasi Risiko Di BMT Sri Sejahtera Pada Kegagalan Teknologi Dan Informasi}

BMT Sri Sejahtera sadar bahwa dalam kegiatan operasionalnya tidak lepas dari teknologi. Oleh karena itu, BMT Sri Sejahtera memitigasi kegagalan sistem untuk mencegah timbulnya gangguan dalam melaksanakan kegiatan operasional. Langkah mitigasi itu adalah pemeliharaan sistem yang meliputi perangkat lunak (software) dan perangkat keras (hardware), serta asetaset yang menunjang kegiatan operasional BMT Sri Sejahtera.
Pemeliharaan terhadap sistem dilakukan secara rutin selama tiga bulan sekali, perwatan juga meliputi fasilitas lainnya seperti air conditioner, printer dll. Serta, selama kurun waktu 1-2 tahun BMT Sri Sejahtera melakukan pergantian unit komputer.

\section{KESIMPULAN DAN SARAN}

\section{Kesimpulan}

Berdasarkan hasil pembahasan dapat disimpulkan BMT Sri Sejahtera melakukan mitigasi risiko pada keberlangsungan proses internal, sumber daya manusia, dan teknologi informasi.

Mitigasi pada keberlangsungan proses internal belum dilaksanakan dengan akurat, seperti kurang memberikan pelatihan kerja terhadap pegawai. Pembinaan pegawai yang berkaitan dengan pekerjaan hanya dilakukan sekali dalam sepekan.

$$
\text { Mitigasi risiko pada }
$$

keberlangsungan proses internal adalah hal pertama yang dilakukan untuk memudahkan kegiatan usaha BMT Sri Sejahtera dalam memberikan pelayanan terhadap calon anggota atau anggota mengenai akad-akad pembiayaan syariah.

\section{Saran}

Saran peneliti terhadap BMT Sri Sejahtera terhadap mitigasi risiko operasional, diharapkan mampu memberikan pelatihan kerja terhadap pegawai. Seminar atau workshop mengenai pembiayaan syariah diperlukan untuk memberikan wawasan yang cukup 
kepada pegawai dalam memberikan layanan kepada calon anggota atau anggota terkait akad-akad pembiayaan syariah.

\section{DAFTAR PUSTAKA}

Alexander, Carol. 2003. Operational Risk: Regulation, Analysis and Management. London: Prentice Hall

Alijoyo, Antonious. 2006. Enterprise Risk Management: Pendekatan Praktis. Edisikedua. Jakarta: PT. Ray Indonesia

Chapra, M. Umer. 2000. Islam dan Tantangan Ekonomi. Jakarta: Gema Insani Press dan Tazkia Institute

Djohanputro. Bramantyo. 2006. PrinsipPrinsip Ekonomi Makro. Cetakan 1. Jakarta: PPM

Frame. J. Davidson. 2003. Managing Risk in Organisations: A Guide for Managers. San Francisco. Jossey Bass: A wiley imprint

Herman, Darmawi. 2008. Manajemen Risiko. Jakarta: Bumi Aksara

IImi, Makhalul. 2002. Teori dan Praktek Lembaga Mikro Keuangan Syariah: Beberapa Permasalahan dan Alternatif Solusi. Yogyakarta: UII Press

Karim, Adiwarman Azwar. 2006. Bank Islam: Analisis Fiqih dan Kevangan. Jakarta: PT. Raja Grafindo Persada

Khan, Tariqullah and Habis Ahmed. 2008. Manajemen Risiko Lembaga
Keuangan Syariah. Jakarta: Bumi Aksara

Mamduh, M. Hanafi. 2009. Manajemen Rlsiko. Yogyakarta: UPP STI Manajemen YKPN

Mirakhor, Abbas dan Zainal labal. 2007. Pengantar Kevangan Islam: Teori dan Praktik. Terjemahan oleh A.K. Anwar. 2008. Jakarta: Kencana Media Group

Mughni, Abdul. 2005. Keuangan Mikro Islam dalam Upaya Pengentasan Masalah Sosial. www.takzia.ac.id, (diaksespada 26 Februari 2017)

Muhammad. 2002. Manajemen Bank Syariah. Yogyakarta: UPP AMP YKPN

Muhammad. 2004. Manajemen Dana Bank Syariah. Yogyakarta: Ekonisia

Redja, George E. 2008. Principles of Risk Management and Insurances. Edisi ke-10. Boston: Pearson International Edition

Sudarsono, Heri. 2004. Bank dan Lembaga Keuangan Syariah Deskripsi dan Ilustrasi. Yogyakarta: Ekonisia

Sugiyono. 2015. Pendekatan Kuantitatif, Kualitatif, dan R\&D. Cetakan Ke-21. Bandung: Alfabeta

Suhendi, Hendi. 2009. Strategi Optimalisasi Peran BMTT sebagai Penggerak Sektor Usaha Mikro. www.fe.unpad.ac.id, (diakses pada 26 Februari 2017)

Yin, K Robert. 2002. Studi Kasus (Desain dan Metode). Jakarta: PT. Raja Grafindo Persada 
Putra, et al/Jurnal Ekonomi Syariah Teori dan Terapan Vol. 6 No. 7 Juli 2019: 1317-1330; ELIMINASI RISIKO OPERASIONAL BMT SRI SEJAHTERA SURABAYA

Yin, K. Robert. 2009. Case Study Research:

Design and Method (4thed.).

California: Sage Publications, Inc.

Yin, K. Robert. 2013. Studi Kasus (Desain dan Metode). Jakarta: PT. Raja Grafindo Persada 